\title{
METHODIC OF GIRL STUDENTS' PROFESSIONALLY SIGNIFICANT COORDINATION QUALITIES' PERFECTION AT PHYSICAL EDUCATION CLASSES
}

\author{
Kolumbet A.N.
}

Kiev National University of Technology and Design

\begin{abstract}
Purpose: implementation of new methodic of professionally significant coordination qualities' training in higher educational establishments' girl students at classes of physical education. Material: 204 girl students participated in the research. Results: in perfection of students' professionally significant coordination qualities it is important to observe certain correlation of exercises in every block of methodic. When planning exercises it is necessary to observe the following correlations: exercises for orientation in space $-32 \%$; exercises for perfection of quickness $-19 \%$; exercises for accuracy of movements and differentiation of muscular efforts $-16 \%$; exercises for balance $-9 \%$. Conclusions: in trainings of professionally significant coordination qualities it is necessary to use different forms of trainings' organization. In preparatory part it is desirable to apply frontal form; in main part - frontal and differentiated-group form.
\end{abstract}

Key words: physical education, coordination qualities.

\section{Introduction}

The realized reforms in modern system of Ukrainian higher education system started mechanisms, making increased requirements to student's personality, content of the mastered knowledge and skills, to student's adaptation to conditions of dynamically and suddenly changing life; to increase of health quality and achievement of high workability; to realization of constant motor rehabilitation [5, 11, 23, 29, and 33]. In these conditions it is important for a personality to understand importance of social cultural factors' influence, which could ensure maximal realization of interests for every person as well as realization of his (her) interests and abilities, realization of healthy life style.

One of factors of students' modern progressing ambiguous situation's solution is physical education. It is called for harmonization of body-spiritual potential; ensure formation of students' complete physical and mental health and achievement of high workability and creative longevity [2, 15, 21, 22, 40, 41]. Just this category of population shall accumulate the highest potential in the shortest time for further build up of society's and state welfare.

As many years' experience and results of scientific researches show [25, 28, 33, 39], during the whole period of study certain part of students have insufficient physical condition and physical fitness. For many times it was proved that existing organization and infrastructure of students' physical education in pedagogic educational establishments do not ensure solution of educational and health related tasks [5, 24, 33]. That is why demand in working out innovative physical education methodic of applied and health related orientation is increasing for them to facilitate increase of students' physical fitness and professional skillfulness.

It is necessary to note that girl students of pedagogic specialties do not practice sports regularly and do not have experience of enduring even easy physical loads. With it, they have problems with health. Many of them do not attend physical education classes regularly. That is why deficit of motor functioning, intrinsic to them, is increasing with every year $[9,11]$. Besides, even physical and motor skills, which they had before entering higher educational establishment, are lost.

Till present time the problem of rising quality of pedagogic higher educational establishments' girl students' physical education has been being solved insufficiently both theoretically and practically. In conditions of traditional organization of physical education there is a contradictory situation, when coordination and professionally significant qualities are not paid attention to enough. In spite of rather significant quantity of scientific works, the desired result has not been achieved. One of variants of this problem's solution can be working out methodic of coordination qualities' training on the base of systemic-structural approach and its realization in physical education process of pedagogic higher educational establishments' girl students. Analysis of students' coordination and professionally important qualities showed that as on to day there are no works on

(c) Kolumbet A.N., 2016

doi:10.15561/20755279.2016.0404 
formation of such abilities at physical education classes. There are also no appropriate methodic for perfection of professionally significant coordination qualities of students at physical education classes. In general only a few publications on this topic exist [1, 17, 18, 27].

High demand in theory and methodic of students' physical education in appropriate scientifically substantiated technologies determined the relevance of our researches.

Hypothesis: we assumed that working out and implementation of methodic of higher educational establishments' girl students' coordination qualities on the base of systemic-structural approach would facilitate improvement of professional indicators, characteristic for pedagogue specialty.

The purpose of the research: working out and implementation of new methodic of professionally significant coordination qualities' training in higher educational establishments' girl students at classes of physical education on the base of systemic-structural approach.

\section{Material and methods}

Participants: in the research $2041^{\text {st }}$ and $2^{\text {nd }}$ year girl students (of 17-21 years' age) of Chernihiv National T.G. Shevchenko Pedagogical University, and Borys Grinchenko Kyiv University, participated. All girl students were related to main health group.

Organization of the research: the research was conducted during 2012-2013. The methodic included blocks, containing special exercises for formation and mastering professionally important coordination qualities.

Experiment was conducted in first and second semesters of academic year. In this period physical education program permits to distribute blocks of exercises for development of girl students' coordination qualities between light athletic trainings, sport games (basketball, volleyball), general physical training. Accordingly, duration of variable part of training session (within our experiment) took not more than 20\% (18-20 minutes) from total time of training. Every group was trained twice a week with 90 minute duration of every class. The worked out by us methodic was designed for 34 weeks (68 classes, 136 hours) with fixed duration of every training.

The blocks of physical exercises for perfection of professionally significant qualities of girl students were used in preparatory and main parts of classes. Breathing and relaxation exercises, games and relay races were used at the end of main and in finalizing parts of trainings. Exercises in blocks were selected as per principle from simple to complex. Blocks with complex exercises lasted from 18 to 20 minutes. Simple exercises were practiced for 10-12 minutes. It permitted to use two blocks with different orientation on girl students' coordination qualities in one training session. Breathing and relaxation exercises were used in the following way: in simple blocks - 12 times; in complex blocks - after every exercise. Special attention was paid to breathing exercises with circle method of training and after work at every station. These exercises took 20 seconds.

In sports games we used physical exercises blocks, which were directed at perfection of girl students' accuracy in reproduction of actions; at response; at differentiation of power parameters. Complication of tasks was realized at the account of application of filled, basketball and volleyball balls, gymnastic sticks, skipping ropes, benches in blocks.

Statistical analysis: for every studied parameter we calculated mean value and mean square deviation. Assessment of confidence of differences was fulfilled by Student's t-criterion at $1 \%$ and $5 \%$ levels of significance.

When fulfilling complex pedagogic and biological examinations we observed Ukrainian legislation about health protection, Helsinki declaration 2000, directive №86/609 of European society about human participation in medical-biological researches.

\section{Results}

Results of study of girl students' coordination qualities showed that all their kinds have rather ambiguous dynamic within $1-4^{\text {th }}$ years of study. With it, a number of indicators worsen significantly till the end of studying period [30-32]. Rather low was general level of girl students' health, their speed power indicators, physical endurance. Insufficient level of most of coordination qualities does not permit to completely form their professionally important qualities.

Correlation analysis showed the presence of close correlation of future pedagogues' professional and coordination qualities [32]. Strong correlation was found between pedagogues' readiness to professional functioning and kinesthetic qualities: accuracy of reproduction of pre-set amplitude of arms' movements; girlstudents ability to hands' fine motor skills with basic coordination, which are covered by concept "Quickness of 
operative thinking". The most significant for students coordination qualities are: accuracy of reproduction, assessment of space, time and power parameters of movements; balance and quickness of responding; orientation in space; quick re-switching of motor functioning; vestibular stability.

We implemented special methodic, which considered correlation of different kinds of basic and professionally important girl students' qualities. The methodic is directed at correction and improvement of indicators. The methodic contains blocks of physical exercises, directed at perfection of the mentioned qualities. In the frames of variable part of general program on physical education the methodic included blocks, containing special exercises for formation and mastering of professionally important coordination qualities:

- Blocks of exercises for orientation in space $(32 \%)$;

- Blocks of exercises for perfection of quickness $22 \%$ );

- Blocks of exercises for perfection of differentiated coordination qualities (19\%);

- Blocks of exercises for accuracy of movements and differentiation of muscular efforts (16\%);

- Blocks of exercises for balance (9\%).

Each block included 4-5 exercises. All blocks were approximately equal by volume of load and time of fulfillment. Blocks' correlations were determined by quantity and level of their density (See fig. 1).

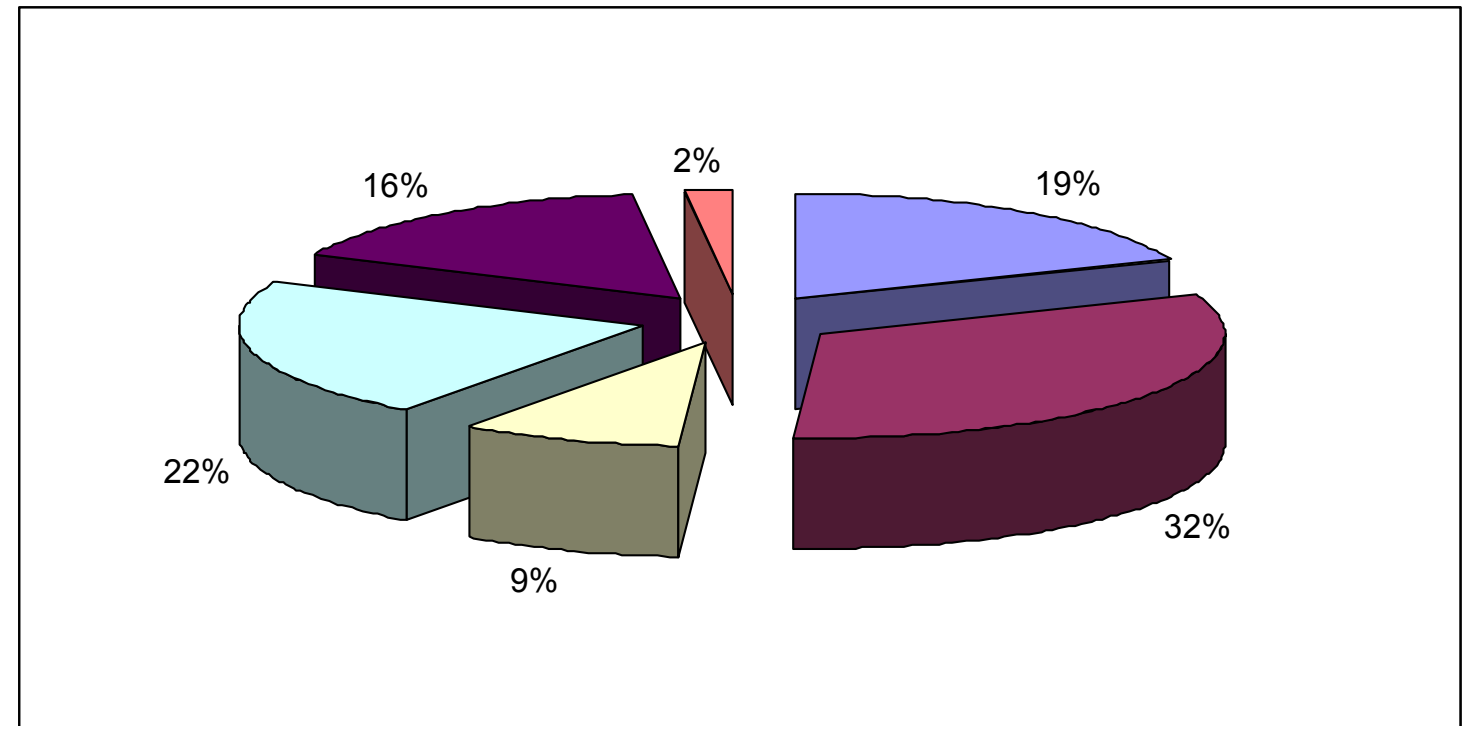

Fig. 1. Correlation of different orientation blocks in methodic of perfection of future specialists' professionally important coordination qualities.

Distinctive feature of the worked out by us methodic was differentiation approach. It permitted to create additional impact on weakly developed coordination abilities, depending on girl students' individual characteristics. When working out the methodic we also considered girl students' individual characteristics.

The main mean of coordination abilities' training were different exercises, which required correctness, speed, rational fulfillment of complex movements from a trainee. Besides, they required inventiveness for these actions' fulfillment in different conditions. We used new, unusual for girl students movements as well as exercises, which were fulfilled with changing either movements and motor actions or conditions of their executions.

For improvement of kinesthetic coordination qualities in experimental group we used tasks for accuracy of differentiation and reproduction of movement's space and power parameters. Exercises were complicated by exclusion of visual control, changing of fulfillment temp, introducing additional distracting movements. We used also "contrast tasks" and "approaching tasks".

For improvement of girl students' responding qualities we used the tasks, based on motion (run exercises, ball dribbling and movement with ball and so on). We used tasks for perfection of simple and complex reactions. The main part of the exercises was realized in section of sport games.

For perfection of static and dynamic balance we used exercises, in fulfillment of which keeping of balance 
was complicated:

- Keeping of different static postures;

- Keeping of balances, movements with small area of support;

- Keeping of movements with complex coordination, requiring efforts for maintaining certain body position; For complicating different exercises and motor actions we used the following methodic techniques:

- Prolongation of time for keeping unstable position;

- Temporary exclusion or restriction of visual control;

- Reduction of support area;

- Introduction of previous or accompanying movements;

- Keeping balance against the background of vestibular apparatus irritation (after movements and turns) and in tired condition.

For improvement of ability to free muscular relaxation we selected exercises (change of free muscular relaxation and tension, breathing exercises, stretching exercises), which were fulfilled in the main part of training session (between main exercises and in finalizing part of training).

In trainings we used the method of strictly regulated exercise: the method of standard-repeated and variable (alternative) exercise; game and competition methods. The repeated method, in conditions of standard fulfillment, was used in the following way: for formation of new skill and mastering of space, time, dynamic and rhythmic characteristics of movement.

The method of variable exercise was used for improvement of already mastered motor skills. We used two variants of this method:

a) Strictly regulated varying (change of movement's direction, change of speed or temp, varying of initial or final positions, change of space restrictions);

b) Not strictly regulated varying (usual motor actions in unusual combinations: complicating of usual action by additional movements; combining of motor actions).

Competition method was used at separate trainings. Introduction of such elements increased motivation for maximally correct motor tasks' fulfillment. It increased efficiency of such trainings. More often this method was used for improvement of girl students' responding qualities.

Sport games were practiced both in control and experimental groups. In their application competition moment was considered. It positively reflected on fulfillment of separate elements by the participants of experimental group. Every game facilitated complex improvement of different coordination qualities of girl students. The program also included relay races [26, 33].

In trainings by the worked out by us methodic we used different forms of trainings' organization. In preparatory (warming up) part we used frontal form. In main part we used frontal and differentiated-group forms. Frontal form required girl students' building in 2-4 lines (instructor shall be in front of lines, in the center). When fulfilling tasks, instructor moves in the gym passing from one edge of line to the other and standing between lines. It facilitated quicker learning of the offered tasks. Besides, we used current method, when equal for all group exercises were fulfilled by the girls in motion following each other by 2-4 persons with definite rest intervals.

With differentiated-group form of trainings' organization, girls were divided into two-three departments. Every department was given task for perfection of physical condition and motor fitness. In every department leader was assigned (the girl with the highest physical fitness), who guided the work of girl students. Instructor watched over the work of all departments and directed, if it was necessary, any department.

When regulating load we considered the following components: load's duration and intensity, duration and character of intervals between exercises, quantity of exercises' repetitions. Duration and character of rest intervals between exercises depended on load. The quantity of repetitions varied depending of complexity of exercise from 4-6 to 10-12 times. 


\section{Discussion}

Coordination qualities are the base of formation of many professionally significant qualities of future specialists. It witnesses about complex negative influence of weak motor functioning on youth [4, 7, 14, 35, 4244].

Dependence of professionally important coordination qualities' development on professionalism of specialists in different spheres was noted in many scientific works [26, 30, 34, 36]. For professional progress in many professions good physical fitness and motor coordination are required. To large extent coordination determines the level of human motor potentials [1, 8, 10, 16, 20, 45, 46].

General principles of future pedagogic profile specialists' training for professional; functioning are reflected in some researches [3, 13, 32]. The authors determine purpose, content, forms and methods of professionalpedagogic and general humanitarian training of future pedagogue. However, the presented data are rather contradictory. It complicates their practical realization.

The techniques of improvement of some coordination qualities' kinds were realized by different researchers $[1,12,18]$. In particular, G.D. Oshchepkov and N.N. Guskova [19] found correlation of motor-coordination qualities with students' physical health and their general physical fitness: the higher physical fitness indicators are the better are coordination qualities. We determined that this correlation directly influences on specialist's professional qualities [14]. With it, this correlation was studied by S.A. Grigoryeva [6] in girl students of economic specialties. Questioning, conducted by the author, permitted to determine coordination qualities, required in active life activity of economic specialists: 1) kinesthetic; 2) responding; 3) rhythmic; 4) orientation. Results of such works correspond to our results. With it, for pedagogues professionally important are: differentiation, kinesthetic, orientation, responding qualities; static and dynamic balance [14]. Marking out of professionally important coordination qualities in specially worked out methodic permitted for us to achieve more progressive growth of pedagogic specialties' girl students' professionalism [31].

Complex approach in this aspect was realized, for the first time, in our works. The used by us methodic techniques of "contrast tasks" and "approaching tasks", for the first time were worked out by V.S. Farfel (19551976) and recommended for application by V.I. Liakh [17] and other specialists [7, 10, 20]. Exercises with simultaneous solution of several tasks improve coordination qualities. Exercises by rigid programs are considered to be less effective. It is connected with the fact that in case of other components' interference in motor system, its operation can significantly worsen $[10 ; 12 ; 20]$. It was proved in our researches [31]. Complex application of means in system of worked out physical education trainings perfects mechanism of coordination and compensation in controlling over movements as well as optimizes correlations of motor qualities, motor speed; improves motorvisual coordination, coordination re-constructions in motor re-switching, accuracy of muscular differentiation [12].

The worked out by us methodic was designed for 34 weeks ( 68 trainings, 136 hours). It corresponds to the data of other scientists. In opinion of other authors effective pedagogic influence in development and improvement of coordination qualities shall take not less than 20 classes [1, 12, and 17].

\section{Conclusions}

1. With improvement of professionally important coordination qualities of a pedagogue it is necessary to observe exercises' correlation in every block of the methodic.

2. When planning exercises in the methodic it is desirable to keep the following correlations: exercise for orientation in space $-32 \%$; exercises for perfection of quickness $-22 \%$; exercises for differential coordination qualities $-19 \%$; exercises for accuracy of movements and differentiation of muscular efforts $-16 \%$; exercises for balance $-9 \%$

3. When practicing perfection of professionally significant coordination qualities it is necessary to use different forms of trainings' organization. In preparatory part it is desirable to apply frontal from. In main part frontal and differentiated-group forms are desirable.

\section{Acknowledgements}

The researches were fulfilled in compliance with direction of scientific program of physical education faculty of Chernihiv National T.G. Shevchenko Pedagogical University, which is a part of university's topic 
"Didactic principles of motor function's formation in persons, who practice physical education and sports" (state registration number

\section{Conflict of interests}

The author declares that there is no conflict of interests.

\section{References:}

1. Afanas'eva IV. Metodika sovershenstvovaniia professional'no znachimykh koordinacionnykh sposobnostej u budushchikh specialistov dizajnerov. Cand. Diss. [Methodic of improvement of professionally significant coordination abilities in future specialists-designers. Cand. Diss.], Omsk; 2008. (in Russian)

2. Bykov VA. Teoretiko-metodologicheskoe obosnovanie kompleksnoj sistemy sportivnoj podgotovki studentov vysshikh uchebnykh zavedenij fizicheskoj kul'tury [Theoretical-methodological substantiation of complex system of sports training of higher educational physical culture establishments' students]. Teoriia i praktika fizicheskoj kul'tury, 2004;2:50-54. (in Russian)

3. Vilenskij MIa, Safin MIa. Professional'naia napravlennost' fizicheskogo vospitaniia studentov pedagogicheskikh special'nostej [Professional orientation of pedagogic specialties' students' physical education]. Moscow: High school; 1989. (in Russian)

4. Gorskaia IIu, Suiangulova LA. Bazovye koordinacionnye sposobnosti shkol'nikov s razlichnym urovnem zdorov'ia [Basic coordination abilities of schoolchildren with different health level], Omsk: SibGUFK; 2000. (in Russian)

5. Grigor'ev VI. Krizis fizicheskoj kul'tury studentov i puti ego preodoleniia [Crisis of students' physical culture and ways of its overcoming], Teoriia i praktika fizicheskoj kul'tury, 2004;2:54-61. (in Russian)

6. Grigor'eva SA. Ekspertnaia ocenka koordinacionnykh sposobnostej, professional'no-znachimykh dlia bakalavrov ekonomicheskogo profilia [Expert assessment of coordination abilities, professionally significant for bachelors of economic profile]. Uchenye zapiski, 2011;5(75):47-50. (in Russian)

7. Zaporozhanov VA, Boraczynski T. Preparation of children with the limited possibilities to tutoring in a comprehensive school - a step to spirituality and humanism. Pedagogics, psychology, medical-biological problems of physical training and sports, 2009;9:52-55.

8. Il'inich VI. Professional'no-prikladnaia fizicheskaia podgotovka [Professional applied physical training], Moscow: High school; 1983. (in Russian)

9. Kabachkov VA, Polievskij SA. Razrabotka professional'no-prikladnoj fizicheskoj podgotovki i opyt ee vnedreniia $\mathrm{v}$ uchebnykh zavedeniiakh proftekhobrazovaniia [Development of professional-applied physical training and experience of its implementation in vocational educational establishments]. Teoriia i praktika fizicheskoj kul'tury, 1980;7;30-34. (in Russian)

10. Kirichenko SI. Professional'no-prikladnaia fizicheskaia podgotovka studentov ekonomicheskogo fakul'tet. Cand. Diss. [Professional-applied physical; training of economical faculty students. Cand. Diss.], Maikop; 1998. (in Russian)

11. Klimakova SN. Determinants of nonfixed locomotors system violations in preschool children. Pedagogics, psychology, medical-biological problems of physical training and sports, 2011;8:36-40.

12. Kogevnikova LK. Education of coordinating capabilities of students on exercises. Physical Education of Students, 2012;1:38-41.

13. Kolumbet AN. Influence of stimulated plasticity training method on coordination indicators of high pedagogic educational estableshments' girl students. Physical Education of Students, 2015;6:31-37. doi:10.15561/20755279.2015.0604

14. Kolumbet OM. Rozvitok koordinacijnikh zdibnostej molodi [Development of youth's coordination abilities], Kiev: Education Ukraine; 2014. (in Ukrainian)

15. Korobejnikov GV. Psikhofiziologicheskie mekhanizmy umstvennoj deiatel'nosti cheloveka [Psychophysiological mechanisms of human mental activity], Kiev; 2002. (in Russian)

16. Korovin SS. Teoreticheskie i metodologicheskie osnovy professional'noj fizicheskoj kul'tury uchashchejsia molodezhi [Theoretical and methodological principles of students' professional physical culture], Moscow: VNIIFK; 1997. (in Russian)

17. Liakh VI. Koordinacionnye sposobnosti: diagnostika i razvitie [Coordination abilities: diagnostic and 
training], Moscow: Division; 2006. (in Russian)

18. Nazarenko LD. Sredstva i metody razvitiia dvigatel'nykh koordinacij [Means and methods of motor coordination training], Moscow: Theory and Practice of Physical Culture; 2003. (in Russian)

19. Oshchepkov GD, Gus'kova NN. Koordinacionnye sposobnosti v pedagogicheskom processe na zaniatiiakh fizicheskoj kul'turoj [Coordination abilities in pedagogic process at physical culture classes]. Uchenye zapiski, 2008;6(40):82-86. (in Russian)

20. Raevskij RT. Professional'no-prikladnaia fizicheskaia podgotovka studentov tekhnicheskikh vuzov [Professional-applied physical training of technical HEEs' students], Moscow: High school; 1989. (in Russian)

21. Bazylyuk TA. Self-evaluation of health and interests of students of higher education institutions on course physical education. Pedagogics, psychology, medical-biological problems of physical training and sports, 2013;7:3-6. doi:10.6084/m9.figshare.735943

22. Beliak YI, Zinchenko NM. Dosing method of physical activity in aerobics classes for students. Physical Education of Students, 2014;5:8-13. doi:10.15561/20755279.2014.0502

23. Belykh SI. Structure of the concept of personality oriented physical education university students. Physical Education of Students, 2013;4:3-9. doi:10.6084/m9.figshare.669663

24. Bryukhanova NA, Bulgakova OV, Mokrova TI, Bogashchenko YA. Determination of possibilities of the use of high-intensive trainings facilities on lessons health aerobics. Physical Education of Students, 2013;2:2529. doi:10.6084/m9.figshare.156376

25. Chernovsky SM, Kolumbet AN. Determination of future designers' professionally important coordination qualities. Physical education of students, 2016;2:38-44. doi:10.15561/20755279.2016.0206.

26. Gorelov AA, Kondakov VL, Usatov AN. To the question about the use of independent physical training in educational space of modern higher institute. Physical education of students, 2013;1:17-27. doi:10.6084/m9.figshare.156351

27. Hirtz P. Coordinative abilities in school sports. Berlin: Volk und Wissen, Volksseigener Verlag, 1985.

28. Iermakov SS, Apanasenko GL, Bondarenko TV, Prasol SD. Physical culture is a basic instrument of culture of health. Pedagogics, psychology, medical-biological problems of physical training and sports, 2010;11:3133.

29. Iermakov SS, Ivashchenko PI, Guzov VV. Features of motivation of students to application of individual programs of physical self-preparation. Physical Education of Students, 2012;4:59-61.

30. Kolumbet AN. Physical education for the students of pedagogical specialities. Science, Technology and Higher Education: III international research and practice conference, Westwood, Canada, January 30, 2014. Westwood, Canada, 2014. P. 34-42.

31. Kolumbet AN. Development of coordination abilities of young people. Science and Education: $V$ international research and practice conference, Munich, Germany, February 27-28, 2014. Munich, Germany, 2014. P. 54-62.

32. Kolumbet AN. Dynamic of girl students' psycho-physiological indicators in process of their study at pedagogical higher educational establishment. Physical education of students, 2016;1:29-36. doi:10.15561/20755279.2016.0104.

33. Kondakov VL, Kopeikina EN, Balysheva NV, Usatov AN, Skrug DA. Causes of declining interest of students to employment physical education and sports. Physical education of students, 2015;1:22-30. doi: $10.15561 / 20755279.2015 .0104$.

34. Korobeynikov G. Psychophysiological Peculiarities of Sexual Dimorphism in Athletes. Psychologe Research, 2012;2(6):336-342.

35. Masliak IP. Physical health of young and middle age women under influence of step-aerobics exercises. Pedagogics, psychology, medical-biological problems of physical training and sports. 2015;10:45-50. doi:10.15561/18189172.2015.1007

36. Pogrebniak IM, Kudelko VE, Nagovitsina OP. Effect of improving aerobics classes at the level of flexibility of female students. Pedagogics, psychology, medical-biological problems of physical training and sports, 2013;5:49-52. doi:10.6084/m9.figshare.707099 
37. Pop C, Ciomag V. The Influence of Aerobic Gymnastics on the Students' Body Image. Procedia - Social and Behavioral Sciences, 2014;117:129-135.

38. Prusik KK, Prusik K, Kozina ZL, Iermakov SS. Features of physical development, physical preparedness and functional state of boys and girls - students of Polish higher educational establishments. Physical Education of Students, 2013;1:54-61. doi:10.6084/m9.figshare.96415

39. Siri A, Rui M. Distance Education for Health Professions' Students. Procedia - Social and Behavioral Sciences. 2015;174:730-738.

40. Usher K, Woods C, Casella E, Glass N, Wilson R, Mayner L, et al. Australian health professions student use of social media. Collegian. 2014;21(2):95-101.

41. von Haaren B, Haertel S, Stumpp J, Hey S, Ebner-Priemer U. Reduced emotional stress reactivity to a reallife academic examination stressor in students participating in a 20-week aerobic exercise training: A randomised controlled trial using Ambulatory Assessment. Psychology of Sport and Exercise. 2015;20:6775.

42. Williams B. Supporting Middle School Students Whose Parents Are Deployed: Challenges and Strategies for Schools. The Clearing House: A Journal of Educational Strategies, Issues and Ideas. 2013;86(4):128135.

43. Wouters S, Duriez B, Luyckx K, Colpin H, Bijttebier P, Verschueren K. Parental goal promotion and college students' self-esteem level and contingency: The mediating role of need satisfaction. Personality and Individual Differences. 2014;66:140-145.

44. Wu H-Y, Wu H-S, Chen I-S, Chen H-C. Exploring the critical influential factors of creativity for college students: A multiple criteria decision-making approach. Thinking Skills and Creativity. 2014;11:1-21.

45. Yahyaei D, Foroushani ZJ, Mahini F. The School Role in Lively Education and Student's Mental Health. Procedia - Social and Behavioral Sciences. 2012;47:1408-1412.

46. Zepke N, Butler P, Leach L. Institutional research and improving the quality of student engagement. Quality in Higher Education. 2012;18(3):329-347. 


\section{Information about the author:}

Kolumbet A.N.; Doctor of Science; http://orcid.org/0000-00018775-4232; re_play@3g.ua; Kiev National University of Technology and Design; st. Nemirovich-Danchenko, 2, Kiev, 14013, Ukraine.

Cite this article as: Kolumbet A.N. Methodic of girl students' professionally significant coordination qualities' perfection at physical education classes. Physical education of students, 2016;4:35-43. doi:10.15561/20755279.2016.0404

The electronic version of this article is the complete one and can be found online at: http://www.sportpedu.org.ua/html/arhive-e.html

This is an Open Access article distributed under the terms of the Creative Commons Attribution License, which permits unrestricted use, distribution, and reproduction in any medium, provided the original work is properly cited (http://creativecommons.org/licenses/by/4.0/deed.en).

Received: 12.07 .2016

Accepted: 19.08.2016; Published: 28.08.2016 